Article

\title{
Perceptions of Socio-Ecological Changes and Their Implications on Changes in Farming Practises and Agricultural Land Uses in the Savannahs of Northeast Ghana
}

\author{
Peter Kojo Boateng 1,*, Divine Odame Appiah ${ }^{2}$, Prince Osei-Wusu Adjei ${ }^{2}$ \\ and Henry Kofi Mensah ${ }^{3}$ \\ 1 Centre for Geography and Environmental Science, Monash University, Melbourne 3800, Australia \\ 2 Department of Geography and Rural Development, KNUST, Kumasi 00233, Ghana; \\ dodameappiah@yahoo.com (D.O.A); poadjei.cass@knust.edu.gh (P.O.-W.A.) \\ 3 Department of Management, KNUST School of Business, Kumasi 00233, Ghana; hkmensah@knust.edu.gh \\ * Correspondence: pboat1985@yahoo.com; Tel.: +61-450-66-7373 \\ Academic Editor: Yu-Pin Lin \\ Received: 11 October 2016; Accepted: 29 November 2016; Published: 1 December 2016
}

\begin{abstract}
This study assesses the perceptions of local farming households in the savannahs of northeast Ghana about the patterns of ecological and social changes happening around them over the years. It then unpacks how those perceptions are influencing farming practices and agricultural land use changes. Theoretical and empirical understandings of the value of local resource users' perceptual judgements about changes in their socio-ecological environment and how they respond to those changes have far-reaching implications for design of agricultural development and sustainable land management policies. Consideration of local perceptions offers more informed basis to design and implement agricultural development policies in ways that encourage active local participation, sustainable livelihoods development, and responsiveness to changing conditions. This departs from current conventional implementation systems, which are usually top-down and based on technical and political aspects of agricultural land management, but do not necessarily comprehend processes influencing the agency of local communities in shaping various agricultural land use outcomes.
\end{abstract}

Keywords: land use; socio-ecological change; perceptions; savannah; Ghana

\section{Introduction}

In the face of rapid changes in the ecology of the highly variable and fragile environments of semi-arid biomes [1,2] and changes in the social structure of the human communities that inhabit those environments, there is a critical challenge for understanding how changes in social systems interact with changes in ecological systems to influence farming practices and agricultural land use trajectories. Thus, this paper aims to make novel contributions to the literature on dryland agricultural management that seeks to understand how human communities in savannah environments perceive changes in their environment and how their responses to those perceived changes help shape various agricultural land use change trajectories. Here, we specifically assess the perceptions of local farming households on the patterns of ecological and social changes happening around them over the years, and we tease out how those perceptions are shaping the production of varied agricultural land uses in the savannahs of rural northeast Ghana.

Although it is widely acknowledged that policy and institutional arrangements at higher scale levels (such as the global, regional, and national scales) have far reaching implications on perceptions and land use decisions at the local community scale [3], this research largely concentrated on the 
influence of changing perceptions about ecological and social environments at the local community level for a number of practical and theoretical reasons. Decisions about farming practices are taken at the farm scale [4], and investigating how rural savannah land users respond to socio-ecological changes/stresses around them reveals much about how their daily livelihood activities are being transformed, and what possible outcomes those livelihood transformations have on changes in patterns of agricultural land use. However, understanding local communities' responses to changing conditions around them first requires an understanding of their perceptions of the changes that are occurring around them. This position is based on the theoretical principle that (changing) perceptions affects behaviours and attitudes [5], and this in turn influences (changing) land use/management practices.

A general situation of lesser state developmental attention over the years has contributed to put many stresses on the daily livelihood portfolios of communities in northeast Ghana [6,7]. Government support for agricultural and development programmes in the northern regions of Ghana has declined sharply since the early 1980s following the severe droughts and the implementation of the structural adjustment programmes backed by the International Monetary Fund (IMF). This situation has created a "development void" in northern Ghana, which is now being increasingly filled through the activities of local and international non-governmental organisations (NGOs) more than through direct government support.

Forces/processes such as population density changes, effects of market forces, technology availability and access, rapid biophysical changes, and national/local government policy orientations contribute to changes in local land management techniques. Local communities' responses to changing socio-economic, environmental and political conditions include different forms of livelihood adaptations and coping strategies, and their ramifications on agricultural land use changes over time are far reaching. While many past studies of perception and responses/adaptations to change largely emphasise descriptions of change patterns and a comparison of these descriptions with official data to test the consistencies of these descriptions [8], this paper contributes to explore local resource users' evaluative modes of explaining causal relationships, predicting further changes, and responding to current and future changes.

\section{Perceptions on Socio-Ecological Environments and Effects on Landscape Conditions: A Literature Review}

There is much consensus in the perceptions literature that populations affected by change (in their ecological and social environment) either adapt to or cope with those changes based on "psychological, social, moral, institutional and cultural processes" [5] (p. 14). Thus, people's perceptions about changes in their human and physical environments and how they respond to those changes are influenced by a number of social and psychological factors such as cultural worldviews, personal experiences and values, level of affectedness by the change, mental imagery of expected versus actual conditions, specific household and farm characteristics, and so on $[9,10]$. For instance, the age of persons greatly affect their resource use experience and their accumulated knowledge of changes in their socio-ecological environment [11,12]. Other studies also suggest that the level of formal education attained by resource users affect their ability to perceive certain socio-ecological changes and their impacts [13]. Again, others suggest that households with more members and engaged in diversified non-farm livelihood strategies that bring in more income are less likely to perceive changes in climate and its effects on farming, especially when their non-farm incomes buffer losses from their farming activities [12,14]. Furthermore, access to support services such as agricultural extension and other technical information is reported to affect farmers' perceptions of ecological changes and their associated costs and benefits for their farming activities [15]. In relation to the factors affecting peoples' perceptions of changes and their associated responses/strategies adopted to cope or adapt to those changes, it is important to clearly point out the distinctions between "perceptual judgement" and "experiential response" [16]. While perceptual judgement relates to human perceptions, judgements, and responses to both eventuated changes and the perceived likelihood of the occurrence of change 
events in the future, experiential response relates more to actions of people in response to eventuated change events.

The distinction between perceptual judgement and experiential response is even more critical when considering perspectives in the literature about perceptions of a forward shift or delay in rainfall onsets in certain semi-arid regions-which are based on respondent interviews/perceptions which relates expected rainfall (usually based on previous years' levels within a certain period) to actual rainfall levels at the same period in another year/season [17]. This call for criticality when assessing perceptions and how perceptions shape processes of sense making in both lay public and expert scientific terms. Within that call for criticality, many past studies of perception and responses/adaptations to change largely emphasise descriptions of change patterns and a comparison of those descriptions with official data to test the consistencies of these descriptions (e.g., [18]). However, this paper goes further to explore local resource users' evaluative modes of explaining causal relationships, predicting further changes, and responding to current and future changes, all in their bid to adapt to and/or cope with eventual changes in their socio-ecological environment.

The relationship between changing perceptions of the socio-ecological environment and land use outcomes is mutually inclusive, implying that changing perceptions influence changing land uses as much as changing land uses influence changing perceptions. For instance, changes in certain land use types, such as conversion of food croplands to cash crop plantations, may be consequential of and/or lead to social-cultural changes in perceptions and conceptions of customary land tenure systems and power relations within a society. These changes in perceptions and conceptions may centre on changing notions of traditional family farms, for example (see Table 5), where farming systems requiring unpaid labour inputs from kinsmen transforms into plantation systems requiring paid labour. Thus, the focus of this present paper is on empirically and theoretically analysing such changing perceptions and notions, which have far reaching implications on farming practises and agricultural land use change trajectories. The consideration of local perceptions offers a more informed basis for designing and implementing agricultural development policies in ways that encourage active local participation, sustainable livelihoods development, and responsiveness to changing conditions. This departs from current conventional implementation systems, which are usually top-down and based on technical and political aspects of agricultural land management [19,20], but do not necessarily comprehend processes influencing the agricultural production and land use decisions of local communities.

\section{Methods}

It is widely acknowledged in the literature that local communities hold vast amounts of knowledge about their socio-economic, political, and physical landscape, dating back to their ancestral occupations of the landscape, that have been passed on from generation to generation (e.g., [21]). Therefore, the insights documented in this paper are based on local knowledge that has been compiled through the communities' lived experiences of their landscape over time. Local perceptions were elicited through focus group discussions and one-on-one interviews with elderly residents in six study communities distributed across three administrative districts (Figure 1) —Naga and Biu in the Kasena Nankana district, Nyariga-Zaare and Zuarungu in the Bolgatanga district, and Teshi and Tilli in the Bawku West district. There were six participants in each focus group and the individual interviews were conducted separately with four elders and long term residents of each community. Thus, 10 people were interviewed in each community, resulting in a total of 60 local residents.

The elders were those who had lived in the communities for long periods and had an appreciable knowledge of changing conditions in their communities and surrounding areas over much longer periods, in some occasions stretching over 70 years. As Eguavoen [22] notes, the possibility of comprehending and evaluating changes around one's environment often increases with age and how much one is affected by those changes. A suite of criteria and their corresponding indicators of changes in the natural environment and socio-economic environment were drawn 
up after initial discussions/interviews with the participants. Table 1 identifies the criteria and their corresponding indicators.

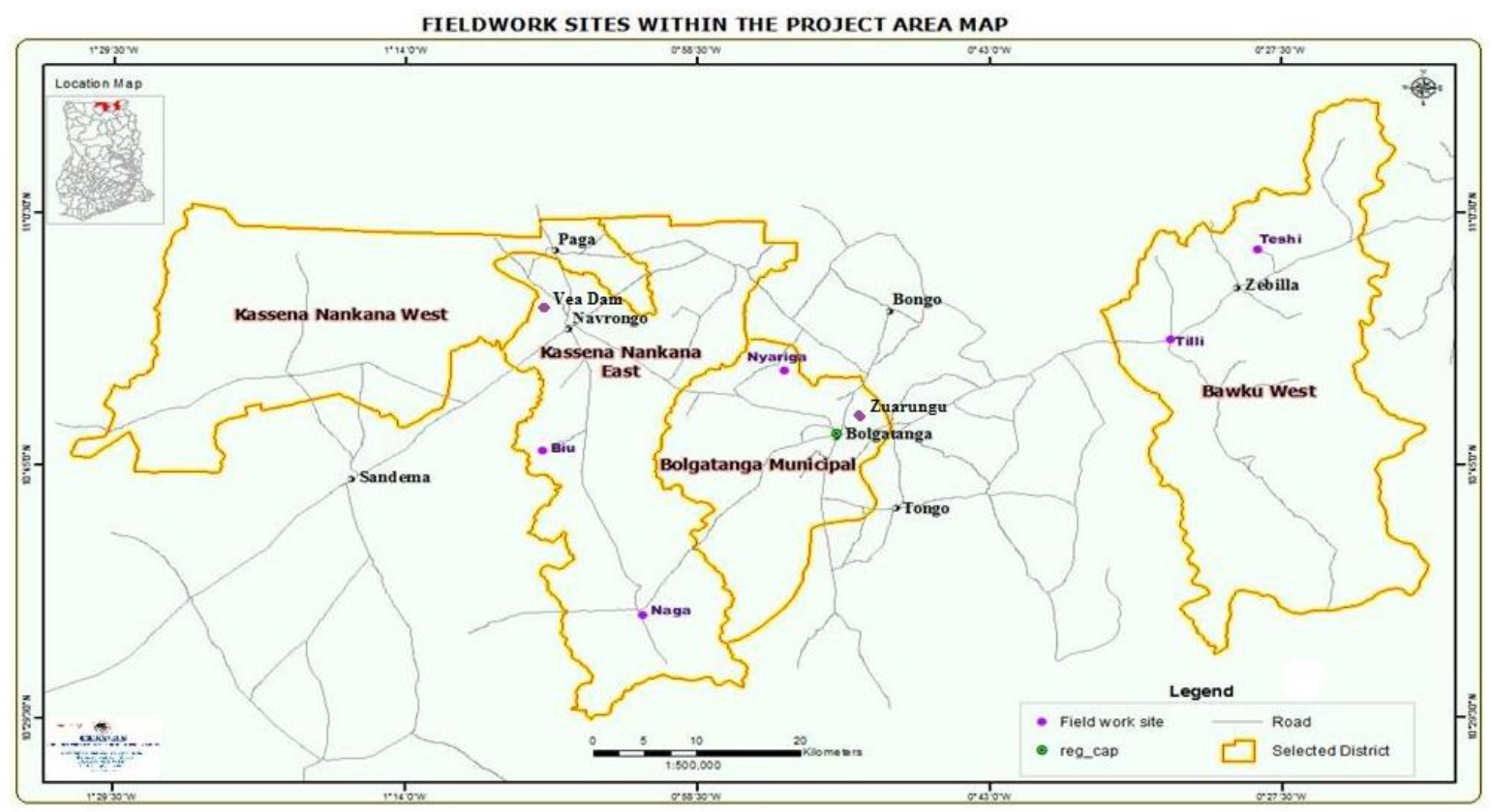

Figure 1. Map of Northeast Ghana showing fieldwork communities in their districts.

Table 1. Criteria and indicators for the perception assessment.

\begin{tabular}{|c|c|c|}
\hline Aspect of Change & Criteria & Perceptive Indicators \\
\hline \multirow{5}{*}{$\begin{array}{l}\text { Changes in the Natural } \\
\text { Environment }\end{array}$} & $\begin{array}{l}\text { Climate and Rainfall } \\
\text { Distribution }\end{array}$ & $\begin{array}{l}\text { Temperature patterns, moisture } \\
\text { availability, weather variations }\end{array}$ \\
\hline & Soil Fertility and Land Area & Land quality, land availability \\
\hline & $\begin{array}{l}\text { Water Availability/Storage } \\
\text { and Irrigation }\end{array}$ & $\begin{array}{l}\text { Rainfall events and occurrences such as } \\
\text { floods, droughts, dry spells, etc. }\end{array}$ \\
\hline & Biological Factors & Incidence of pests and diseases \\
\hline & Livestock & $\begin{array}{l}\text { Abundant livestock types and number } \\
\text { of herds per hectare of land }\end{array}$ \\
\hline \multirow{4}{*}{$\begin{array}{l}\text { Changes in the } \\
\text { Socio-Cultural and Economic } \\
\text { Environment }\end{array}$} & $\begin{array}{l}\text { Land Tenure and } \\
\text { Agricultural Production }\end{array}$ & $\begin{array}{l}\text { Changes in customary land tenure } \\
\text { arrangements. Influence/position in } \\
\text { society to, among others, access and/or } \\
\text { accumulate labour of others, land, } \\
\text { financial resources, support from } \\
\text { governmental and non-governmental } \\
\text { agencies, etc. }\end{array}$ \\
\hline & Demographic Structure & $\begin{array}{l}\text { Changes in demographic structure } \\
\text { through migration, fertility, } \\
\text { and mortality }\end{array}$ \\
\hline & Market Forces & $\begin{array}{c}\text { Effects of changing market } \\
\text { demand/prices on agricultural land use, } \\
\text { dynamics in land commoditization, and } \\
\text { the land market }\end{array}$ \\
\hline & Political Factors & Chieftaincy disputes, political instability \\
\hline
\end{tabular}

Focus group participants and elders were asked about the major changes they had observed in their area over the course of their living memory and to describe whether these had positive or 
negative outcomes. Participants were then asked how these changes had affected their livelihood activities over the years. All the respondents for the interviews were farmers who work the land to cultivate food crops (mainly millet, guinea corn), cash crops (vegetables, maize, cotton, etc.), as well as rear livestock (cattle, sheep, goats, guinea fowls, fowl, etc.) and collect products from tree crops such as shea trees (Vitellaria paradoxa) and "dawadawa" (Parkia biglobosa).

We also compared respondents' perceptions of changes in rainfall conditions in their area with official long-term rainfall data collected by the Ghana Meteorological Agency. We compiled yearly rainfall data from 1960 to 2012, as complete records of monthly rainfall data for the study areas was only available from 1960 onwards. The comparative analysis enabled us to identify the connections and disconnections between the perspectives of local farmers on the ground and the trends portrayed in the official government data. For the official rainfall data, a simple polynomial regression for yearly trend analysis was conducted using Microsoft Excel. We determined the coefficient of determination (i.e., $R$-squared or $R^{2}$ ), which is a statistical measure to test the correlation of highly variable data and determine the direction of the correlation. $R$-squared values range between -1 and 1 . An $R$-squared value of 1 or close to 1 suggests a strong positive correlation, an $R$-squared value of 0 or a positive figure closer to 0 suggests a weak or insignificant positive correlation. On the other hand, a negative $R$-squared value suggests a negative correlation.

Next, we discuss the participants' perceptions on each criterion they identified to describe the changes they were observing.

\section{Results}

\subsection{Perceptions and Responses to Environmental Changes/Stresses}

\subsubsection{Climate and Rainfall Distribution}

Respondents in each focus group were asked if they had heard the term "climate change" and if yes, what they thought about it. The interviews revealed that the majority of farmers had not heard of the term "climate change" nor had much to say about their perceptions of climate change. There were no distinctive local terms for "climate change". However, when we asked them about changes in rainfall and temperature, they responded positively. Use of the phrase "changes in accustomed yearly weather patterns" was more practically appropriate in eliciting perceptions about climatic variability. Table 2 summarises farmers' perceptions in simple "yes" and "no" terms about occurrences of climate variability over their living memories, sometimes stretching over 60 years back.

Table 2. Farmers' responses when asked if they had perceived changes in accustomed weather patterns.

\begin{tabular}{ccc}
\hline Response & Frequency & Percentage (\%) \\
\hline Yes & 51 & 85 \\
No & 9 & 15 \\
Total & 60 & 100 \\
\hline
\end{tabular}

Table 2 shows that most respondents indicated that they had observed noticeable changes in yearly weather/climate, and only a few said there were no noticeable changes. Land users in the districts agree about some form of changes to observed patterns of climatic elements (such as rainfall and temperatures) that they were accustomed to in the past. For the $15 \%$ of respondents who indicated no noticeable changes in rainfall and climate conditions, we asked them to give their reason. Although some farmers in this category acknowledged changes in rainfall patterns and crop production, they attributed these to "spiritual" and "moral" breakdown in the communities. They explained that irregular rainfall and poor harvests are acts of God as punishment for their peoples' dwindling reverence to the Earth God and ancestral spirits. They felt the "natural" conditions could be restored if the people followed proper local customs. 
Among the respondents who agreed there were noticeable changes in rainfall and climate conditions, the specific changes observed are presented in Table 3.

Table 3. Perceptions on changes in specific climate elements.

\begin{tabular}{ccc}
\hline Response & Frequency & Percentage (\%) \\
\hline High Rainfall & 2 & 4 \\
Low Rainfall & 13 & 25.4 \\
Unstable General Weather Patterns & 28 & 55 \\
Prolonged Dry Season & 4 & 7.8 \\
High Temperatures & 4 & 7.8 \\
Total & 51 & 100 \\
\hline
\end{tabular}

Of the 51 respondents, more than half identified "unstable general weather patterns" as the main manifestation of climate variability. In other words, they felt the variability was not about high rainfall or low rainfall or high/low temperatures, but a combination of these in an irregular cyclical pattern. Many perspectives in the current academic literature cite these primary accounts of "irregular pattern" of climate to support their argument about occurrence of climate change, but such perspectives are generated partly due to the use of structured multiple-choices interview responses (e.g., see $[17,23,24])$. Of those who responded that their observed changes related to low rainfall, the underlying explanation by one respondent from Naga in the Kasena Nankana district captures their reason:

"Yes, I have observed some considerable change in accustomed weather patterns. We have had to move our farming season forward from mid-April to the middle or sometimes latter parts of May as the period from which we receive reliable rains have been delaying, and the amount of rain is drastically low sometimes." (Respondent 14, Kasena Nankana District, Naga Village)

For the farmers who indicated "unstable general weather patterns" as their response, this explanation by one farmer captures their reason:

"I cannot say we are only seeing changes that relate to just increasing or decreasing rainfall and temperature conditions. Sometimes we get rain in excess, other times we get less rain, sometimes we get just about the right conditions of rainfall for our crops to thrive. But no matter the change, we still sow every year, although we sometimes experience less production on our farms mainly because of a drought or low rainfall." (Respondent 36, Bolgatanga District, Zaare village)

The variety and conflicting nature of the responses about changes in observed weather patterns illustrates that individuals' perceptions of those changes depend on their lived experiences and value judgements of those changes on their livelihoods and community in general. Importantly, the diversity of the responses suggests whatever changes that the local people have observed in weather and climate patterns, those changes indicate no specific direction but multiple variations along a continuum of change. This directly relates to the high variability of climatic and weather patterns in dry sub-humid regions [2,25]. Figure 2, for example, represents long-term rainfall data collected at the Zuarungu weather station located in the study area, showing the highly cyclical variability of local climate parameters such as rainfall. 


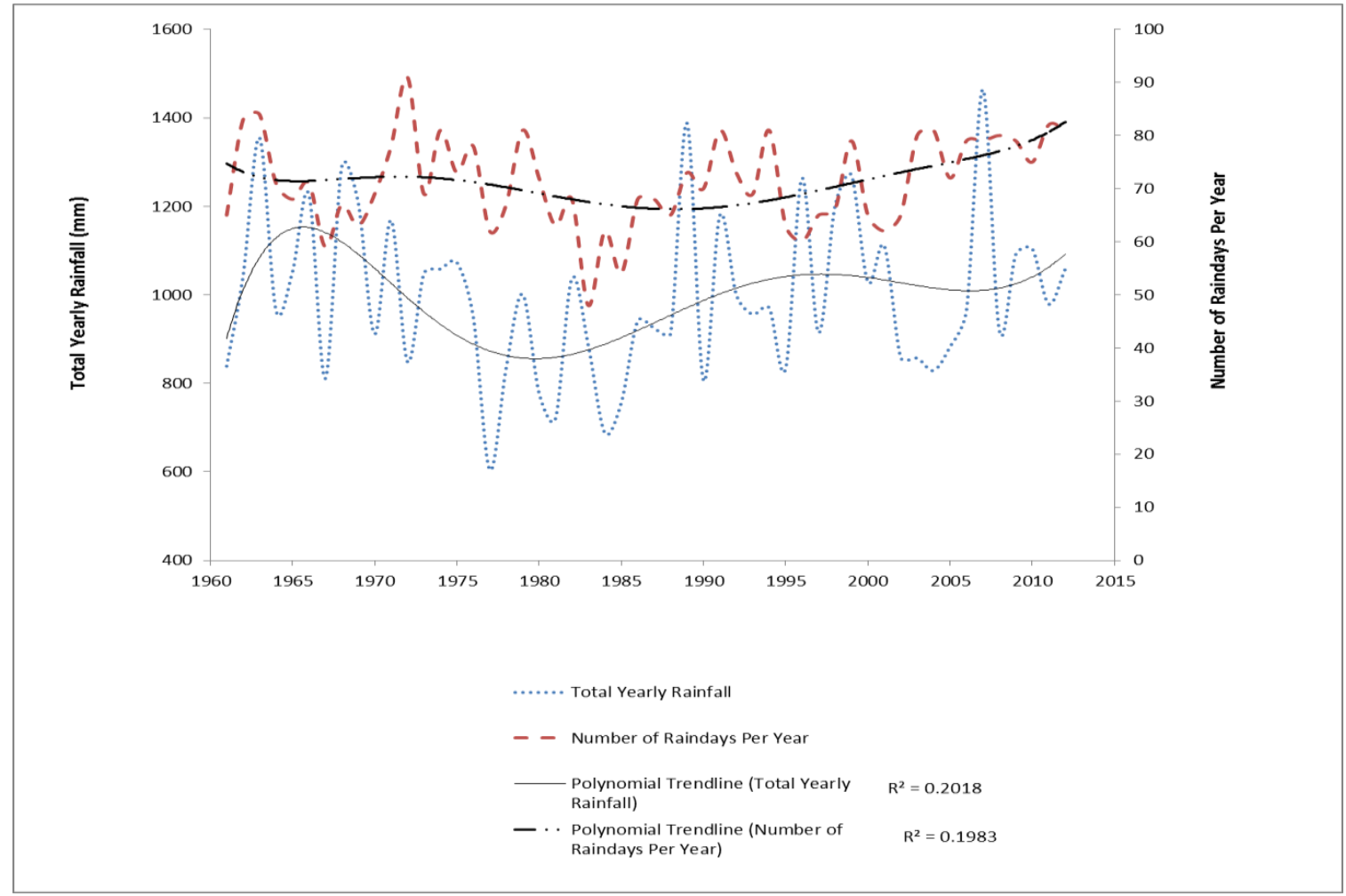

Figure 2. Annual rainfall and rainfall intensity distribution for Zuarungu station, 1961-2012. Source: Authors, based on data obtained from Ghana Meteorological Agency.

The data from the Zuarungu weather station show high inter-annual rainfall variability from 1961 to 2012. The yearly rainfall distribution is characterised by a pattern of inconsistent variability from year to year. The variability is non-linear, thus changing in several forms, from a year of increasing rainfall to an immediate next year of decreasing rainfall to a combination of consecutive years when rainfall increases or decreases. However, when a simple polynomial regression is run for the yearly rainfall data, the results show a positive coefficient of determination, although it is a weak positive correlation (see $R^{2}$ or regression coefficient calculations in Figure 2).

Respondents were also asked about periods when they experienced extreme climate events such as droughts or flooding, how it affected their livelihoods, and how they responded to them. Occurrences of droughts and low rainfall stood out more in participants' memories than did occurrences of floods or excess rainfall. The droughts and bushfires that swept through northern Ghana in the early 1980s were still very fresh on participants' minds. The following comment by one participant captures the general perception about the frequency of drought and flood occurrence, how detrimental or beneficial they are, and what their causes are:

"We are used to droughts and some periods of very high rainfall in this area. Periods of very low rainfall is a constant feature of the rainfall situation in this area. In the past, majority of our crops used to survive the drought periods until some good rains fall, but nowadays we are losing more crops when rainfall becomes very bad. There are some periods when we receive a lot more rainfall on our lands than will be required, sometimes destroying our crops and farmlands. But at least such high rainfall periods help increase the fertility of my lowland farms because the rains transport and deposit manure there." (Respondent 39, Bolgatanga district, Zuarungu village)

From the quote above, it is possible to discern why droughts and low rainfall periods dominate general indigenous comprehension (i.e., what is felt and observed and how to make sense of the observed) of rainfall conditions. The adverse effects of droughts and low rainfall periods on biomass 
(re)production are harshly felt on agricultural livelihoods, and they are usually more severe than the effects that high rainfall events or even flooding have on agricultural livelihoods. At least high rainfall periods contribute to some form of soil enrichment (such as nutrient deposition in lowlands), whereas decreases in agricultural production on many occasions are attributed to low rainfall and droughty periods.

Respondents were further asked about how those observed climatic changes affected their decisions about their farming activities and land use in general. They narrated that they have had to experiment with their land preparation, planting, and sowing calendar for many crops to adjust to those climatic changes. For instance, the early millet varieties are planted and sowed around late April and early May just in time to provide food for the 'hunger season' when most of the food produced during the previous farming season would have been consumed. Farmers complained that irregular rainfall patterns sometimes delayed their planting of the early millet, therefore affecting food security during the hunger season. Usually, the practise is to wait until the first or second rains during the start of the raining season in mid-April before preparing land and planting (see Table 4). However, some farmers plant early in anticipation of (good) rains whilst others wait until the onset of the first rain before they plant. Those who plant in anticipation are usually the well-to-do ones who have enough seeds and can afford to "try their luck". Those without that many seeds simply wait and "try their luck" with some few seeds. Thus, it can be discerned from the explanations above that the intensification, or lack thereof, of agricultural land use activities goes a long way to influence farmers' perceptions of apparent weather and climate changes. For instance, socio-economic needs (or incentives) for earlier planting of crops than in previous times may help increase exposure and awareness to certain climatic conditions at certain times, and thus help consolidate certain perceptions about apparent climate changes. 
Table 4. General cropping calendar for major crops in upper east region.

\begin{tabular}{|c|c|c|c|c|c|c|c|c|c|}
\hline Crop & April & May & June & July & August & September & October & November & December \\
\hline $\begin{array}{l}\text { Millet (early and } \\
\text { late varieties) }\end{array}$ & Land Prep & $\begin{array}{l}\text { Land prep } \\
\text { and planting }\end{array}$ & $\begin{array}{l}\text { Planting and } \\
\text { weeding }\end{array}$ & Weeding & $\begin{array}{c}\text { Harvest (early } \\
\text { varieties) }\end{array}$ & - & $\begin{array}{c}\text { Harvest (late } \\
\text { varieties) }\end{array}$ & $\begin{array}{l}\text { Harvest and } \\
\text { process }\end{array}$ & $\begin{array}{c}\text { Harvest and } \\
\text { process }\end{array}$ \\
\hline Sorghum & Land Prep & $\begin{array}{l}\text { Land prep } \\
\text { and planting }\end{array}$ & $\begin{array}{l}\text { Planting and } \\
\text { weeding }\end{array}$ & Weeding & Weeding & - & - & $\begin{array}{l}\text { Harvest and } \\
\text { process }\end{array}$ & $\begin{array}{c}\text { Harvest and } \\
\text { process }\end{array}$ \\
\hline Groundnut & Land Prep & $\begin{array}{c}\text { Land prep } \\
\text { and planting }\end{array}$ & Weeding & Weeding & Harvest & Harvest & $\begin{array}{l}\text { Dry and } \\
\text { process }\end{array}$ & $\begin{array}{l}\text { Dry and } \\
\text { process }\end{array}$ & - \\
\hline Maize & Land Prep & $\begin{array}{l}\text { Land prep } \\
\text { and planting }\end{array}$ & Planting & $\begin{array}{l}\text { Weeding and } \\
\text { planting }\end{array}$ & Weeding & - & Harvest & $\begin{array}{l}\text { Dry and } \\
\text { process }\end{array}$ & \\
\hline Cowpea & Land Prep & $\begin{array}{l}\text { Planting and } \\
\text { weeding }\end{array}$ & Weeding & - & - & - & Harvest & $\begin{array}{c}\text { Harvest and } \\
\text { process }\end{array}$ & \\
\hline Rice & Stump-ing & Land prep & Planting & $\begin{array}{l}\text { Fertilizer and } \\
\text { weeding }\end{array}$ & Weeding & Fertilizer & - & $\begin{array}{l}\text { Harvest and } \\
\text { process }\end{array}$ & $\begin{array}{c}\text { Harvest and } \\
\text { process }\end{array}$ \\
\hline
\end{tabular}




\subsubsection{Soil Fertility and Land Area}

The farming systems in northeast Ghana have been often characterised as a low-input-continuouscultivation system where available land is heavily used but with little or no fallow and/or addition of fertility enhancing inputs such as manure, fertilizers, green compost, among others (e.g., see [26,27]). It was therefore interesting to elicit perceptions and observe at firsthand how local farmers in the various study areas manage the maintenance of soil fertility/quality on their farmlands. Soil quality in this context refers to the ability of soils to effectively provide essential nutrients and other physical properties necessary to effectively support reasonable crop production.

The interviews revealed the most commonly used method of soil fertility management in all the districts was the application of organic nutrients in livestock manure, household organic wastes and green composts, and other on-farm plant wastes. Another interesting method of soil fertility management is the planting and maintenance of Acacia albida trees on farmlands. The respondents claimed these trees are important for enhancing the fertility and productivity of farmlands on which they grow, especially when their leaves drop and decompose on the land to supply essential organic nutrients. Another method employed to enhance fertility is the application of chemical fertilizers, but this method was less popular among the farmers interviewed due to higher prices. Many respondents explained that their expenditures on expensive artificial fertilizers did not always yield the expected outcomes on crop production, especially during periods of low rainfall and inadequate water supply. Another reason for the unpopularity of chemical fertilizers is that they felt that the effect was not as lasting for the soil as organic manure. They felt that constant application of inorganic fertilizer causes the soil to be acidic and hardens the soil.

Land fallowing as a method of rejuvenating fertility of soils is less common in some of the districts. In the Bolgatanga district, increasing population density has culminated in the increasing fragmentation of land such that land resources available to individual households are becoming too small to practise land rotation and/or swidden agriculture. However, loss of some fallow time on farmlands in the Bolgatanga district is augmented by the application of manure and chemical fertilizers. In the Kasena-Nankana and Bawku West districts, land fallowing is still widely practised, although the length of fallow may have been reduced over the years. While the application of fertility enhancing manure and fertilizer is concentrated at the compound farm and reduces on farms further away, land fallowing is mostly concentrated on bushlands further away and reduces the closer the land is to the compound. These findings suggest that local farmers are actually active in the application of fertility enhancing inputs on their farmlands, although fallow periods are reducing, and seem to contradict the popular notion in the literature about a low-input farming system.

Although farmers are actively enhancing fertility on their farmlands, there are some challenges. Farmers cited occasional shortages of manure and organic materials for mulching. Decreases in livestock numbers, grazing and roaming of livestock in open areas away from enclosed spaces, and non-ownership of livestock affected the availability of manure. Also, the usage of plant/crop residues, such as the stems and leaves of millet plants, for fire making and feeding animals affects their availability for mulching purposes.

Perceptions were divided on the conditions of soil quality over the years. On one hand, about $60 \%$ of the respondents noted that there have been considerable deteriorations of farm soil quality over the years, negatively affecting crop production. They attributed such soil quality deterioration mainly to constant cultivation of the land with reducing fallow periods and inadequate application of fertilizer due to high costs. They also perceived soil quality deterioration by taking note of the increasing amounts of animal manure they have to apply to their fields before the soil can be enriched enough to support reasonable agricultural production. They noted that they used to apply relatively smaller amounts of manure in the past compared to what the soil now requires. The majority of the $60 \%$ of respondents who thought that soil conditions had deteriorated were from the Bolgatanga district, where population density is relatively higher. On the other hand, about $40 \%$ of the respondents perceived that there has been no recognisable decline in soil quality over the years, and that there 
have rather been some improvements in soil quality as evidenced in relatively higher crop yields in recent times. They were, however, quick to also attribute some recent increases in crop yields to the introduction and adoption of improved seed varieties and better farming practises.

The respondents recounted the importance of finger millet (or early millet) for instance, describing how they mature early than the pearl millet and yield more grains. Improved varieties of maize, rice, groundnuts, millets and many other crops were introduced to the areas by governmental and non-governmental agencies from the 1970s onwards. While there is no official data on regular soil fertility assessments to compare how the farmers' perceptions relate with them, the differing views show perceptions about changes in soil fertility conditions are subjective and household-specific, and based on individual choices about crops grown, seed types, fertilizer access, and other resource endowments. Thus, many relatively well-to-do households with better access to good seeds, adequate manure, and other resource endowments perceived soil conditions to be generally stable or improved, while the majority of those who perceived adverse changes in soil quality conditions were from relatively poorer households.

\subsubsection{Water Availability/Storage and Irrigation}

Many of the farmers also partly attributed the improved production of crops to increasing avenues for dry season gardening made possible by relatively improved stored water availability over the dry season. Some of the respondents recounted the effects of the spread and rehabilitation of irrigation facilities such as water reservoirs, dams, and deep water wells, especially from the 1990s onwards. The military governments of Ghana during the 1970s (i.e., National Redemption Council from 1972 to 1975 and the Supreme Military Council from 1975 to 1978) emphasised the transformation of the northern regions into the food basket of the country. Thus, the major irrigation dams in the Upper East region-the Vea Dam in the Bolgatanga district and the Tono Dam in the Kasena-Nankana district - and many other small dams were built from this time onwards. The completion of major irrigation infrastructure, such as the Vea Dam in the Bolgatanga district and the Tono Dam in the Kassena-Nankana district, brought about several changes in land use and land cover. For instance, there have been rapid expansions of commercial rice and vegetable farming around valleys and tributaries of major rivers in the area [28]. There are reports of some more than 250 irrigation facilities (e.g., dams, reservoirs, small dugouts) in the Upper East region alone, with each average irrigation facility having the capacity to irrigate about 10 hectares of land [28].

Cash crops such as rice, onions, sweet potatoes, tomatoes, lettuce, and watermelons are cultivated in commercial quantities on the irrigated plots. However, whilst crops like onions are gaining increasing preference on irrigated plots, others like rice are losing importance. Rising costs of inputs and lessening attractiveness of the market for locally produced rice following the influx of cheaper but quality rice imported from elsewhere onto the Ghanaian market has affected rice cultivation, and many plots on the irrigation sites are not in use. Onions and tomatoes have gained greater prominence on the major irrigated plots and other smaller irrigation/dam sites, although market "middlemen" use the quick perishability of tomatoes to dictate prices to their favour when buying them from farmers. However, onions are not easily perishable, and farmers use market information available to them through the use of mobile phones and other communication exchange forms to decide where and when to sell their onions for favourable prices. One reason farmers gave for the importance of tomatoes although they are prone to price manipulations from market "middlemen" was that not only is the tomato market booming but its cultivation required less labour and it is easier to harvest and sell.

\subsubsection{Biological Factors}

Regarding biological factors such as incidence of pests and diseases, the respondents also made several observations. First, older respondents interviewed, especially those in the Kassena-Nankana and Bawku West districts, were acutely aware of land use changes wrought by the presence and distribution of insects that cause diseases to humans and livestock around the valleys (lowlands) 
and marshy areas surrounding the major rivers in their district. Tsetse flies (which cause sleeping sickness or Trypanosomiasis) and the blackfly or Simulium damnosum (which causes river blindness or Onchocerciasis) were the predominant disease vectors [29]. Other identified disease vectors, such as Schistosoma worms (which cause Schistosomiasis or bilharzia) and malaria-carrying mosquitoes are more reported at places where flowing and stagnant water bodies are found.

The older respondents recounted episodes in their own living memory and stories passed on to them about a cyclical colonization and decolonisation of land around the fertile land surrounding major rivers and streams as a result of the activities of these pests. Indeed, community perceptions about the activities and behaviours of the disease vectors have influenced patterns of settlement and agricultural land use especially along the areas surrounding the major rivers and streams in the region. During periods of low disease vector activity in the dry seasons, mild droughts and famines pushed migrants to colonize unsettled and fertile land in close proximity to rivers and streams. Farmlands expanded as other existing land covers (such as bushlands and dense woodlands) were transformed; the choice of crops grown may have expanded when the settled land supported a wider range of crops. On the other hand, during periods of high disease vector activity especially in the raining season, (some) migrant communities retreated to other areas less affected by disease vectors. As populations retreat, farmlands were recolonized by shrubs and other vegetation covers. Older respondents interviewed in Naga in the Kassena-Nankana district recounted that their parents settled permanently in their present location after the then government introduced tsetse fly eradication programmes. Tsetse fly eradication campaigns in the northern regions of Ghana started from 1932 to 1949 (e.g., see [29,30]). However, blackfly eradication campaigns were delayed as the then colonial government was mainly preoccupied with eradicating the tsetse flies to protect livestock, which was a very important source of tax revenues for the government [29].

\subsubsection{Livestock}

The majority of the respondents also recounted changing numbers of livestock owned by households. Regarding cattle especially, they explained that they own fewer herds now than in the past. They attributed this situation to incidence of diseases, theft, and the fact that many children who traditionally shepherd herds of livestock in the past are now being enrolled in school, thus decreasing their availability to shepherd. Quite frequently in the past, cattle and other livestock were allowed to roam and forage freely in the dry season but were confined in kraals during the wet season, as depicted in Figure 3. The increasing practise of dry season farming has created conflicts with herders as a result of herds of animals entering unfenced farms and eating/destroying planted crops. These conflicts over the years have partly necessitated the confinement of cattle, goats, and sheep in kraals for most parts of the year.

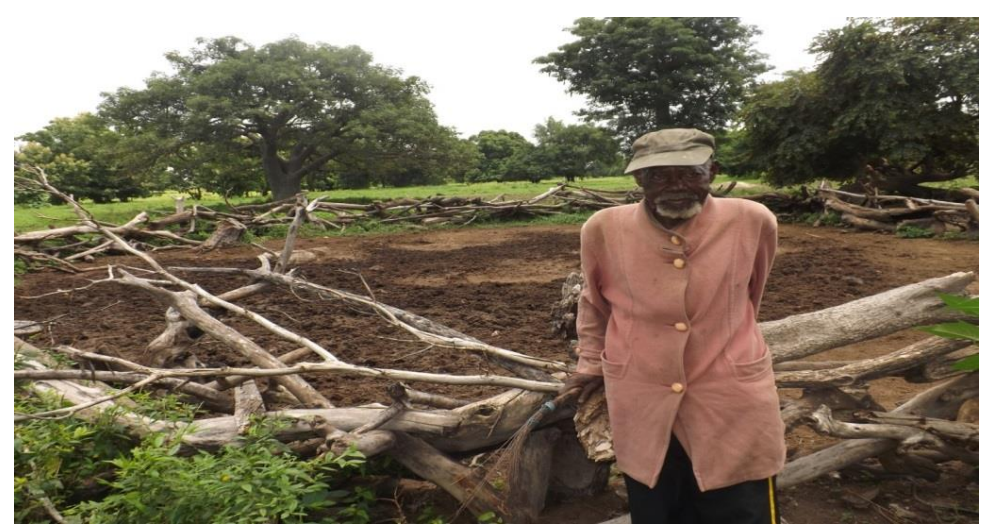

Figure 3. Farmer in Kasena Nankaka district in front of his kraal. Source: Authors, with permission from respondent, 2013. 
The respondents were positive about improved veterinary care and animal housing conditions. They noted increased numbers of pigs (mainly reared by non-Muslim women) and other reared animals in the poultry category (such as chicken, guinea fowls, turkeys, and ducks). Donkeys have also become very common such that most households own at least one. They explained further that improved livestock management conditions are beneficial not only for meat production, but also for ploughing and carting of goods (especially oxen and donkeys) and production of manure to enrich soils with organic nutrients. Changes in improved animal care and housing conditions contribute to collection of more manure per farmer than in the past where livestock was allowed to roam freely during the dry season.

\subsection{Perceptions and Responses to Socio-Cultural and Economic Changes/Stresses}

The identified changes/stresses in this domain included changes in customary land tenure systems, social organisation, political (in)stabilities, and changes in demographic structure through migration, fertility, and mortality.

\subsubsection{Land Tenure}

Land tenure and access systems in the study areas have undergone some major changes. Most of these changes were brought about mainly as a result of the enactment of the Land and Native Rights Ordinance in 1927 during the colonial era and the passage of the State Lands Acts of 1962 in the post-independence era. The Lands and Native Rights Ordinance sought to vest all lands, whether occupied or unoccupied, in the direct control of the Governor of colonial Ghana purportedly on behalf of the natives. The State Lands Act of 1962 was passed after political independence, and it declared all lands in Ghana as vested in the Office of the President in trusteeship for the "public good of Ghana". The main difference between the two is that while the former did not make any provisions for payment of monetary compensation for those whose lands were taken, the latter did provide some monetary compensation but those payments were reported to be far below the market value of the land. Other minor amendments to land legislation have been made after 1962. Generally, these measures have gradually changed a purely customary system of land tenure to a system that is largely dominated by private ownership and market forces [31]. Thus, lands that have been held in custody by Tindanas (i.e., earth priests) and families and chiefs under usufructuary access systems are now being increasingly converted to private legal ownership, with the right to sell to any agreed buyer. This new trend is different from the customary land tenure system in the past, especially during the pre-colonial era, where land and other natural resources are held by communities (under the guardianship of the earth priest), and access/use by families or clans or individuals are governed by usufruct rights and other traditional practices. In this system, the position of every land holder was said to be "titular", holding the land on behalf of the whole community [32].

Among the most significant changes wrought by land tenure changes have been the increasing economic value of land and reduction of uninhabited or unfarmed land in the study areas, especially in the Bolgatanga Municipality. In the past, uninhabited lands in the "bush" were under the spiritual oversight of the Tindaana (earth priest), who allocated land to households or families or clans that requested for them as long as the necessary traditional rites were met. Unused bushland is, however, still in bountiful supply in parts of the Kasena-Nankana district, around major river valleys and other areas that were heavily infested with disease vectors and pests before past governments embarked on major pest spraying/eradication programmes from the mid-1930s.

The rising economic value of land makes it difficult for cash-poor farmers in highly populated areas to access more land (i.e., land outside their family land unit) if they want to. The richer folks, many from outside the communities themselves, are buying up more land mostly for non-agricultural uses, but also for some agricultural purposes. This system is gradually eroding the traditional egalitarian system of land tenure, and resulting in land use changes such as increasing conversion of staple crop farmlands for production of cash crops and other non-agricultural uses. It is also creating 
unequal access rights to land. This situation may partly explain why gaining access to more land in the Bolgatanga Municipality especially is very difficult for many farmers, and many of them are diversifying to non-farm livelihood sectors to supplement their farming livelihoods.

Although the practise of borrowing unused land from friends or relatives to supplement one's own farming activities has been in existence for long in the study areas, land leasing or renting by monetary payments is a fairly recent phenomenon. Households that have put all their land into productive cultivation and still have enough labour and capital resources rent or lease others' unused land if they can afford and the land is available. Many relatively well-to-do farmers in the Bolgatanga and Bawku West districts were found to engage in this practise, and sometimes hire the labour of those people from whom they borrowed or leased the land from. Thus, past practises of not accessing land through financial transactions and transfers have largely decayed, with land resources now being increasingly commercialised and available so far as there is a willing seller and buyer. Limited or inadequate access to productive resources such as labour and capital compels some farmers to sell off part of their land for capital. Other farmers also migrate to seek other opportunities in the national capital and other cities in the southern part of the country. In the process, they sell their land or give it out to family or friends to use whilst they are away.

A positive perception in the study areas about changes in the customary land tenure system is that there has been increased ownership and permanent access to land by women. In all the study areas, it was reported that women can now legally own land through inheritance (from family or dead spouse) or outright purchase, although in practice many women do not have the financial resources to acquire land. This is a shift from customary land tenure arrangements in the past where women only had use rights to the land of their families or spouses but not outright ownership or allodial allocation of their own land. Djokoto and Opoku [32] also observed the same trend in their study of land tenure changes in northern Ghana. Increasing female ownership and access to land more often translates into increasing use of land for production of crops that are mostly cultivated by women, such as vegetables and cover crops (e.g., beans, cowpeas), although traditional cereals like millet and guinea corn are also cultivated by women. Many women cultivate vegetable and cover crops which they mostly sell at local markets to supplement their income from other sources.

\subsubsection{Demographic Structure}

Another factor of socio-cultural change that the respondents perceived to have wide ranging effects on land use and settlement patterns was changes in population and the demographic structure. Respondents reported increases in the population of their villages, as confirmed by the official government data in Tables 5 and 6.

Table 5 shows that the population of the entire Upper East region grew from 468,638 in 1960 to $1,046,545$ in 2010, with varying levels of inter-censual growth rates. Table 6 also shows that the populations of the study areas have increased substantially, with most increases concentrated in the Bolgatanga district. The respondents explained that rapid population increases in the past were due to a common practise where people gave birth to more children and lived in large family compounds. The expectation was that some of the children would die before maturity and that the few surviving children would provide labour to work on their farms. However, improvements in antenatal care, family planning, a lowering of mortality, and increasing living costs have brought some major changes in the family compound structure such that people are now giving birth to fewer children and smaller units of nuclear families are now living alone in their own compounds [31] —although they still maintain strong extended family ties. Respondents explained that it is easier to manage the social and economic life of nuclear families. This finding was found to have important implications not only on dependency ratios in the study areas, but also importantly on farmland types and cropping patterns. 
Table 5. Regional population dynamics 1960-2010.

\begin{tabular}{cccccc}
\hline Parameter & $\mathbf{1 9 6 0}$ & $\mathbf{1 9 7 0}$ & $\mathbf{1 9 8 4}$ & $\mathbf{2 0 0 0}$ & $\mathbf{2 0 1 0}$ \\
\hline Total Population & 468,638 & 542,858 & 772,744 & 920,089 & $1,046,545$ \\
\% Share of Total Population & 6.9 & 6.3 & 6.3 & 4.9 & 4.2 \\
$\begin{array}{c}\text { Population density per Person sq. } \mathbf{~ k m} \\
\text { \% Annual Population Growth Rate }\end{array}$ & 53.0 & 61.4 & 87.4 & 104.1 & 118.4 \\
\end{tabular}

Land Area $\left(\mathrm{km}^{2}\right)$ for region is 8842 , representing 3.7\% of Total Land Area of Ghana. Source: [32].

Table 6. Study community population dynamics, 1970-2000.

\begin{tabular}{ccccc}
\hline District & Community & $\mathbf{1 9 7 0}$ & $\mathbf{1 9 8 4}$ & $\mathbf{2 0 0 0}$ \\
\hline \multirow{2}{*}{ Bawku West } & Teshi & - & 281 & 336 \\
& Tilli & 50 & 693 & 980 \\
\hline \multirow{2}{*}{ Kasena Nanakana } & Biu & 907 & 1166 & 2748 \\
& Naga & 721 & 896 & 1604 \\
\hline \multirow{2}{*}{ Bolgatanga } & Zaare & 719 & 2084 & 4915 \\
& Zuarungu & 1218 & 3314 & 4552
\end{tabular}

Figures for Certain Years Missing for Some Enumeration Areas in the Various Communities Source: [33].

On the lower dependency ratio domain, many nuclear families now have fewer mouths to feed, such that traditional use of land to cultivate food crops like millet and guinea corn is facing some competition from use of land for cultivation of cash crops such as vegetables and maize for sale on local and regional markets. On the farmland types and cropping pattern domain, disintegration of large extended families into several nucleated families redistributed the organisation of agricultural land use. Table 7 below presents a categorisation of the general organisation of agricultural land use for individual households.

Table 7. Cropping patterns and farmland types.

\begin{tabular}{|c|c|c|c|c|}
\hline Farmland Type & Main Crops & Cropping Pattern & Secondary Crops & Cropping Pattern \\
\hline \multirow{4}{*}{ Compound Farm (Farm 1) } & Millet & Mixed & Maize & Mono \\
\hline & Sorghum & Mixed & Okro & Mono \\
\hline & Beans & Mixed & Groundnuts & Mixed \\
\hline & & & Cowpea & Mixed \\
\hline \multirow{4}{*}{ Family Farm (Farm 2) } & Millet & Mixed & Maize & Mono \\
\hline & Sorghum & Mixed & Rice (nursery) * & Mono \\
\hline & Beans & Mixed & Kenaf & Mono \\
\hline & Groundnuts & Mono & Pepper & Mono \\
\hline \multirow{5}{*}{ Bush Farm (Farm 3) } & Sorghum & Mixed & Rice $^{* *}$ & Mono \\
\hline & Millet & Mixed & Mango & Mono \\
\hline & Beans & Mixed & Maize & Mono \\
\hline & Tomatoes & Mono & Cotton & Mono \\
\hline & & & Kenaf & Mono \\
\hline \multirow{3}{*}{ Irrigated Plots (Farm 4) } & Rice & Mono & Tomatoes & Mixed \\
\hline & Onions & Mono & Lettuce & Mono \\
\hline & Sweet Potatoes & Mono & Water melons & Mono \\
\hline
\end{tabular}

* Rice nurseries on family farms. Households that have rice nurseries on family farms usually have access to irrigated plots where the nursed rice is transplanted onto; ${ }^{* *}$ Bush farms with rice cultivated on them are usually those that are located in lowland valleys, floodplains, or marshy areas close to water bodies.

On the compound farms surrounding farmers' compound homes, staples like millet, sorghum, and beans, and to some extent groundnuts, dominate the crop choice, just as for all the farm types except the irrigated plots where commercial cash crops like rice and vegetables dominate. Millet, sorghum, and beans are grown in mixed stands intercropped with each other. However, secondary 
compound farm crops such as maize and okro are usually mono-cropped in pure stands whereas secondary leguminous crops serving as cover crops, such as groundnuts and cowpea, are usually intercropped with other crops. These farms usually provide the main subsistence source to the household, thus fertility improvement on them receive the most attention and it is easier to transfer livestock manure and other household organic waste onto them for soil fertilisation.

On the family farms (i.e., farm 2), the choice of crops is not that different from the compound farms, although other leafy plants and vegetables such as kenaf (Hibiscus cannabinus) and pepper are mono-cropped on them. Some rice may also be grown on the family farms, but these are usually rice nurseries. The nursed rice will be transplanted onto other swampy and suitable cultivation areas, usually on irrigated sites. Usually, the purpose of family farms is to supplement the farm produce obtained from compound farms and to provide an insurance against crop failure on the compound farms due to livestock destruction or any other reason.

Some households also have farmlands in the bush, often some kilometres away from the compound house or community. Apart from the usual staple crops grown on bush farms, a variety of cash crops are also cultivated on them. People with lands around swampy areas of the bush, such as along floodplains and riparian areas cultivate some rice. Others cultivate commercial tree crops such as mangoes and kenaf (Hibiscus cannabinus) in a plantation style. It was observed that households that have bush farms are generally well-to-do as they engage in the production of cash crops and have sizeable number of livestock which they rear and sell for cash to meet needs.

In the past, it was common to find extended family households having at least three farmland types to farm on and support their large extended families (i.e., comprising of types 1, 2, and 3, or sometimes 4 depending on irrigation facility availability and access). Increasing fragmentation of large extended family households into several separate smaller nuclear units has affected the organisation outlined above. It is now common to find individual households having at least two separate farmland types to farm on-compound farms that immediately surround a compound house and supplementary family farms which usually range from a distance of a few yards away from the compound farm to some considerable distance in the bush. Generally, the closer a farmland is to the compound house, the more relatively fertile and intensively used that piece of land, as there is constant supply of manure and other organic or inorganic nutrients to the soil. With the effects of the fragmentation of large extended family units on the organisation of agricultural land use notwithstanding, many well-to-do farmers in all three districts were also observed to have up to two additional separate spaces of farmlands which are more devoted to the production of commercial crops such as rice and maize. These additional farmlands are mostly around irrigation project sites and/or in the distant bush.

Another aspect of demographic change that cannot be overemphasized is the effects of the multiplicity of ethnic groups in same areas on land-use/cover patterns. The respondents recounted that it was common to find members of a single ethnic group residing in an area. However, the dominance of single ethnic groups is declining as more areas are becoming ethnically diverse as a result of migrations and inter-ethnic marriages. Many perceive these ethnic mixes to be beneficial for socio-economic development in that they brought about symbiotic effects such as knowledge transfers and more avenues for business. For instance, the settling of nomadic Fulani expert herdsmen in Naaga and other communities in the Kassena-Nankana district enabled many local farmers to concentrate on their crop farming while their livestock were tended to expertly by the Fulanis at an agreed cost. Also, emigration of people from the Bawku East Municipality into the neighbouring Bawku West District as a result of land disputes in the former had enormous effects on land-use/cover patterns in the latter. For instance, many farmers in the Bawku East district who originated from other districts were able to acquire land from locals on arranged basis such as share-cropping or leasing or lending, and these lands were converted to agricultural land uses that were not necessarily deemed "traditional" in the Bawku West district, such as plots utilized for agroforestry purposes and the planting of crops favoured elsewhere. 


\subsubsection{Market Forces}

Respondents were also asked about their perceptions on the influence of economic factors such as market integration and agricultural produce prices in their land use decisions. The consensus among the older respondents was that before the 1970s there was little incentive to produce surpluses, sell on the market, and maximise profits. This is because local economies in northern Ghana were less commercialised or monetized at the time and there was no real government support for smallholder farmers. Yaro [6] also confirms that being farthest away from the centre of business and economic radiation in Ghana (i.e., Accra, the capital city of Ghana and the other major business centres like Kumasi) and a general situation of lesser state developmental attention over the years has contributed to more economic stresses on livelihood portfolios in northeast Ghana. However, the interviewees recounted how conditions changed from the 1970s when the severe drought of the Sahel region hit their area hardest. They responded to the then military governments' economic initiative of reviving the food crop sector to address a nationwide food-deficient situation that persisted at the time. Thus, a lot more land was devoted to the production of food crops.

Respondents were also asked to describe agricultural production and land use systems at their localities during the implementation period of the Economic Recovery and Structural Adjustment Programme from 1983 to 1991. Government support for cash/export crop production encouraged more farmers towards the production of commercial food crops for domestic consumption and for sale on local and national markets. Crops such as maize, rice, and vegetables gained increased prominence because the government provided comparatively significant support for their production (e.g., through measures that made inputs such as fertilizers and tractors readily accessible to a lot of farmers), and they could be easily sold on the local markets as a result of improvements in road transport and other marketing facilities. Other food crops like millet and guinea corn were still in production to some extent but the fact that almost every household grew those crops made them not very marketable. Thus, more land formerly devoted to millet and sorghum production before the 1980s were converted for the production of commercial cash crops like maize, cotton, and vegetables, and even rice if irrigation facilities and/or swampy land could be accessed. Other free lying land covers may also have been transformed to agricultural lands. These findings confirm Abdulai and Huffman's [34] conclusion that farmers and other land users in northeast Ghana respond highly to changes in input and output market conditions, and that profit maximisation is now a very common purpose for use of land.

The respondents unanimously perceived that increasing household expenditures and needs for cash has also made profit maximisation of farming a necessity. They observed how an increasingly monetized economy, especially from the 1980s onwards, has propelled them to increase land under agricultural production (i.e., extensification) and use more farm inputs (i.e., intensification), all other factors of production being constant. Recurrent expenditures on household bills such as school fees, utility bills, hospital fees, and contributions to traditional ceremonies such as weddings and funerals were commonly cited as a feature of the monetized economy. Thus, although there are now more avenues to generate income from farming and other land uses (although output price increases have been nominal), the general perception is that increasing needs for cash is making them money poor. A very common response to money poverty in northeast Ghana is migration to southern Ghana where people generally perceive that there are more economic opportunities.

The effects of migration (both seasonally and permanently) on changes in land use in the study areas of this research work in opposite directions. On one hand, there was some significant number of returnee natives who were affected by labour retrenchment drives as part of the government's Economic Recovery and Structural Adjustment Programme, and many of these returnee retrenched labourers took to agriculture to make ends meet. On the other hand, there has also been a long history of significant migrations of people from the study areas to southern Ghana where state developmental attention and job opportunities in large private enterprises such as cocoa plantations have been concentrated. In both directions of migration, there are significant effects on agricultural land use and land cover. A common causal factor in both directions of migration is the effects of prevailing economic 
conditions/opportunities/stresses and changes/reforms in economic policy orientations over time, although other factors such as land availability and ethnic conflicts were also cited. Over $90 \%$ of the interviewed households have at least one relative who has migrated for 12 months or more to other regions of Ghana (mostly in the south), mostly for work and other economic purposes. Only 22\% of all interviewed households had relatives or household members who have migrated outside their community and/or region for purposes other than economic, such as schooling.

\subsubsection{Political Factors}

Finally, the respondents also perceived that political instabilities and ethnic conflicts also had significant marks on land use decisions and land-use/cover change patterns in general. Although none of the study areas chosen for this study have any experience of major ethnic wars/conflicts from the twentieth century onwards, respondents were aware of land-use/cover change patterns in their areas that are partly generated by ethnic tensions elsewhere. Respondents in the Bawku West District, which borders the conflict-prone Bawku East Municipality to the west, attributed decreasing spatial extent of densely wooded areas partly to increasing immigration of peoples from the Bawku East Municipality as a result of tribal conflicts happening there. Thus, agricultural land use in the Bawku West district may have increased as more uninhabited land in the interior were put into agricultural use by farmers escaping tribal conflicts and political instabilities in the Bawku East Municipality. Sporadic tribal conflicts in the Bawku municipality are essentially chieftaincy and land control disputes, and date as far back as 1929 when the British colonial administration first introduced plans to re-demarcate the then Northern Territories of the Gold Coast into smaller administrative districts and appoint local chiefs through whom to practise indirect rule [35]. The conflicts heightened from 1981 onwards as a result of government and political interference, with succeeding governments enacting decrees and implementing their solutions to the conflicts, which were considered by factions in the conflicts to favour their rivals depending on which government was in power.

\section{Discussion}

Changing biophysical, socio-cultural, and economic conditions in the savannah regions of West Africa have received some considerable attention in the literature (e.g., [11-16]). The literature indicates that changes are occurring across various temporal and spatial scales, and savannah land users in different contexts have various perceptions of these changes, but investigations of savannah land users' dynamic responses to those changes have lagged behind in the literature. Savannah land users' responses to changes in the socio-ecological environment reveal much about how their daily livelihood activities are being transformed, and what possible outcomes those livelihood transformations have on agricultural land use changes.

The respondents in this study had varying perceptions on changes in rainfall and climate conditions, although the majority reported generally unstable conditions in rainfall and weather patterns. The diversity of the perceptions indicated that those changes related to no specific unidirectional trajectory of change but multiple variations along a continuum of change. While the respondents expressed concerns about how increasing unpredictability of rainfall affects their farming decisions, changes in agricultural land use and livelihood strategies are also driven significantly by socio-economic and political developments/changes such as dynamics in land access, inputs access/availability, and changing family structures and social relations of production.

Although about $60 \%$ of respondents also perceived that there have been adverse changes in soil conditions and land cover while the remaining $40 \%$ perceived there to be stable and/or improved conditions in soil conditions, those who perceived adverse changes in soil and land cover quality were relatively poor and had limited access to prime agricultural lands, fertilizer/manure, and improved seeds and other inputs compared to those who reported stable and/or improved conditions of soils. Thus, the analysis revealed that perceptions about changes in soil fertility conditions are subjective 
and household-specific, based on individual choices about crops grown, seed types, fertilizer/manure access, and other resource endowments of households.

While official government discourse portrays alarming rates of land degradation and desertification in the study areas, the most pressing concerns reported by local people on the ground relate to sustaining their livelihoods to cope and/or adapt to recurrent conditions they have observed as part of the natural environment (such as high climate variability and occasional extreme weather events) and other changes they are observing (such as land and labour access, inputs access, changes in market conditions, and so on). We emphasize here that consideration of these local perceptions offers a more informed basis for designing and implementing agricultural development policies in ways that encourage active local participation, sustainable livelihoods development, and responsiveness to changing conditions such as climate change.

\section{Conclusions}

The paper analysed the perceptions of smallholder farmers in the savannah areas of northeast Ghana regarding the biophysical and socioeconomic changes and concomitant changes in farming practises and agricultural land use. We gathered data mainly from participatory workshops and interviews, but also used governmental statistics and published secondary data to gauge how the perceptions compare to other documented indicators of changing conditions. The analysis identified and discussed local communities' perceptions on a broad range of social, economic, political, and ecological factors that are constantly changing and influence's farmers' decisions on their farming practises. The paper espouses that farmers' perceptions on changing conditions and how those changes influence their land use decisions ought to be genuinely considered to enhance the responsiveness of agricultural land use management policies to issues such as the influence of climate change.

Acknowledgments: The authors are thankful to Monash University for providing generous financial support for this study. We also thank Haripriya Rangan, Christian Webersik and Simon Batterbury for providing expert advice on initial drafts of this paper. We are also grateful to the respondents in the study communities who shared their stories with us, and to the Ghana Statistical Service and Ghana Meteorological Agency for providing secondary data. Finally, we also wish to thank the two anonymous reviewers who provided constructive critique on this paper.

Author Contributions: Peter Kojo Boateng designed the survey instruments and wrote the first draft of the manuscript. Divine Odame Appiah, Prince Osei-Wusu Adjei and Henry Kofi Mensah contributed in analyses and revisions of the draft manuscript. All authors read and approved the final manuscript.

Conflicts of Interest: The authors declare no conflict of interest.

\section{References}

1. Reynolds, J.F.; Fernández, R.J.; Kemp, P.R. Drylands and Global Change: Rainfall Variability and Sustainable Rangeland Production. In Proceedings of the 12th Toyota Conference: Challenge of Plant and Agricultural Sciences to the Crisis of Biosphere on the Earth in the 21st Century, Tokyo, Japan, 25-28 November 1998.

2. Hulme, M. Climatic Perspectives on Sahelian Desiccation: 1973-1998. Glob. Environ. Chang. 2001, 11, 19-29. [CrossRef]

3. Maro, P. Environmental Change in Lesotho: An Analysis of the Causes and Consequences of Land-Use Change in the Lowland Region; Springer: Amsterdam, The Netherlands, 2011; pp. 14-18.

4. Gutzler, C.; Helming, K.; Balla, D.; Dannowski, R.; Deumlich, D.; Glemnitz, M.; Knierim, A.; Mirschel, W.; Nendel, C.; Paul, C.; et al. Agricultural Land Use Changes-A Scenario-based Sustainability Impact Assessment for Brandenburg, Germany. Ecol. Indic. 2015, 48, 505-517. [CrossRef]

5. Reser, J.P.; Bradley, G.L.; Glendon, A.I.; Ellul, M.C.; Callaghan, R. Public Risk Perceptions, Understandings, and Responses to Climate Change and Natural Disasters in Australia and Great Britain; National Climate Change Adaptation Research Facility: Gold Coast, Australia, 2012; pp. 7-15.

6. Yaro, J.A. Is Deagrarianisation Real? A Study of Livelihood Activities in Rural Northern Ghana. J. Mod. Afr. Stud. 2006, 44, 125-156. [CrossRef] 
7. O'Higgins, R.C. Savannah Woodland Degradation Assessments in Ghana: Integrating Ecological Indicators with Local Perceptions. Earth Environ. 2007, 3, 246-281.

8. Elgin-Stuczynski, I.R.; Batterbury, S.P.J. Perceptions of Climate Variability and Dairy Farmer Adaptations in Corangamite Shire, Victoria, Australia. Int. J. Clim. Chang. Strateg. Manag. 2014, 6, 85-107. [CrossRef]

9. Dessai, S.; Adger, W.N.; Hulme, M.; Turnpenny, J.; Köhler, J.; Warren, R. Defining and Experiencing Dangerous Climate Change: An Editorial Essay. Clim. Chang. 2004, 64, 11-25. [CrossRef]

10. Leiserowitz, A.A. American Risk Perceptions: Is Climate Change Dangerous? Risk Anal. 2005, 25, 1433-1442. [CrossRef] [PubMed]

11. Marx, S.M.; Weber, E.U.; Orlove, B.S.; Leiserowitz, A.; Krantz, D.H.; Roncoli, C.; Philips, J. Communication and Mental Processes: Experiential and Analytic Processing of Uncertain Climate Information. Glob. Environ. Chang. 2007, 17, 47-58. [CrossRef]

12. Juana, J.S.; Kahaka, Z.; Okurut, F.N. Farmers' Perceptions and Adaptations to Climate Change in Sub-Sahara Africa: A Synthesis of Empirical Studies and Implications for Public Policy in African Agriculture. J. Agric. Sci. 2013, 5, 121-135. [CrossRef]

13. Debela, N.; Mohammed, C.; Bridle, K.; Corkrey, R.; McNeil, D. Perception of Climate Change and its Impact by Smallholders in Pastoral/Agropastoral Systems of Borana, South Ethiopia. SpringerPlus 2015, 4, 236. [CrossRef] [PubMed]

14. Mustapha, S.B.; Sanda, A.H.; Shehu, H. Farmers' Perception of Climate Change in Central Agricultural Zone of Borno State, Nigeria. J. Environ. Earth Sci. 2012, 2, 21-28.

15. Ndambiri, K.; Ritho, C.; Mbogoh, G.; Ng'ang'a, I.; Muiruri, J.; Nyangweso, M.; Kipsat, J.; Omboto, I.; Ogada, O.; Kefa, C.; et al. Analysis of Farmers' Perceptions of the Effects of Climate Change in Kenya: The Case of Kyuso District. J. Environ. Earth Sci. 2012, 2, 74-83.

16. Maddison, D. The Perception of and Adaptation to Climate Change in Africa; The World Bank: Washington, DC, USA, 2007; pp. 38-42.

17. Dinar, A.; Hassan, R.; Mendelsohn, R.; Benhin, J. Climate Change and Agriculture in Africa: Impact Assessment and Adaptation Strategies; Earthscan: London, UK, 2008; pp. 36-48.

18. Guthiga, P.; Newsham, A. Meteorologists Meeting Rainmakers: Indigenous Knowledge and Climate Policy Processes in Kenya. IDS Bull. 2011, 42, 104-109. [CrossRef]

19. Kutter, A.; Ulbert, V. The Impact of the Participatory Approach to Land Use Planning. In Land Use, Land Cover and Soil Sciences: Encyclopaedia of Life Support Systems (EOLSS); Verheye, W.H., Ed.; EOLSS Publishers: Paris, France, 2002.

20. Nidumolu, U.B.; de Bie, C.A.J.M.; van Keulen, H.; Skidmore, A.K.; Harmsen, K. Review of a Land Use Planning Programme through the Soft Systems Methodology. Land Use Policy 2006, 23, 187-203. [CrossRef]

21. Griggs, D.; Lynch, A.; Joachim, L.; Zhu, X.; Adler, C.; Bischoff-Mattson, Z.; Wang, P.; Kestin, T. Learning from Indigenous Knowledge for Improved Natural Resource Management in the Barmah-Millewa; Final Report to the Victorian Centre for Climate Change Adaptation Research, MSI Report 13/1; Monash Sustainability Institute, Monash University: Melbourne, Australia, 2013.

22. Eguavoen, I. Climate Change and Trajectories of Blame in Northern Ghana. Anthropol. Noteb. 2013, 19, 5-24.

23. Laux, P.; Kunstmann, H.; Badossy, A. Predicting the Regional Onset of the Rainy Season in West Africa. Int. J. Climatol. 2007, 28, 329-342. [CrossRef]

24. Derbile, E.K. Reducing Vulnerability of Rain-fed Agriculture to Drought through Indigenous Knowledge Systems in North-eastern Ghana. Int. J. Clim. Chang. Strateg. Manag. 2013, 5, 71-94. [CrossRef]

25. Giannini, A.; Biasutti, M.; Verstraete, M.M. A Climate Model-Based Review of Drought in the Sahel: Desertification, the Re-greening and Climate Change. Glob. Planet. Chang. 2008, 64, 119-128. [CrossRef]

26. Cleveland, D.A. Migration in West Africa: A Savanna Village Perspective. Afr. J. Int. Afr. Inst. 1991, 61, 222-246. [CrossRef]

27. Webber, P. Agrarian Change in Kusasi, Northeast Ghana. Africa 1996, 66, 437-457. [CrossRef]

28. Dietz, T.; Millar, D.; Dittoh, S.; Obeng, F.; Ofori-Sarpong, E. Climate and Livelihood Change in Northeast Ghana. In The Impact of Climate Change on Drylands: With a Focus on West Africa; Dietz, T., Ruben, R., Verhagen, A., Eds.; Kluwer Academic Publishers: Dordrecht, The Netherlands, 2004; pp. 149-172.

29. Wardell, A.D. Collision, Collusion and Muted Resistance: Contrasting Early and Later Encounters with Empire Forestry in the Gold Coast; 1874-1957. In Collisions of Cultures and Identities: Settlers and Indigenous Peoples; McGregor, R., Ed.; University of Melbourne Press: Melbourne, Australia, 2006; pp. 79-103. 
30. Hunter, J.M. River Blindness in Nangodi, Northern Ghana: A Hypothesis of Cyclical Advance and Retreat. Geogr. Rev. 1966, 56, 398-416. [CrossRef]

31. Dietz, T.; van der Geest, K.; Obeng, F. Local Perceptions of Development and Change in Northern Ghana. In Rural Development in Northern Ghana; Yaro, J., Ed.; Nova Science Publishers: New York, NY, USA, 2013; pp. 16-18.

32. Djokoto, G.; Opoku, K. Land Tenure in Ghana: Making a Case for Incorporation of Customary Law in Land Administration and Areas of Intervention by the Growing Forest Partnership; International Union for the Conservation of Nature and Growing Forest Partnership: Gland, Switzerland, 2010; pp. 5-7.

33. Ghana Statistical Service. 2010 Population and Housing Census: Upper East Regional Analytical Report; Ghana Statistical Service: Accra, Ghana, 2012; pp. 15-52.

34. Abdulai, A.; Huffman, W. Structural Adjustment and Economic Efficiency of Rice Farmers in Northern Ghana. Econ. Dev. Cult. Chang. 2000, 48, 503-520. [CrossRef]

35. Lund, C. Bawku is Still Volatile: Ethno-political Conflicts and State Recognition in Northern Ghana. J. Mod. Afr. Stud. 2003, 414, 587-610. [CrossRef]

(C) 2016 by the authors; licensee MDPI, Basel, Switzerland. This article is an open access article distributed under the terms and conditions of the Creative Commons Attribution (CC-BY) license (http://creativecommons.org/licenses/by/4.0/). 